Věda a perspektivy № 2(9) 2022

ISSN 2695-1584 (Print)

ISST 2695-1592 (Online)

https://doi.org/10.52058/2695-1592-2022-2(9)-132-141

\title{
Петро Волошин
}

доцент кафедри музикознавства та вокально-хорового мистецтвва, заслужений працівник культури Украӥни.

Уманський державний педагогічний університет імені Павла Тичини.

м. Умань, Україна,

https://orcid.org/0000-0002-6235-8003

\section{ВОКАЛЬНО-ВИКОНАВСЬКА МАНЕРА, ЯК ТВОРЧИЙ ЧИННИК СУЧАСНОГО ВОКАЛЬНОГО МИСТЕЦТВА}

Анотація. У статті здійснені систематизація й узагальнення відомостей про особливості вокально-виконавської манери як творчого чиннику сучасного вокального мистецтва. Саме поняття “вокально-виконавська культура" інтегрує у собі численні складові професійного співу і $€$ визначальним показником гарного співака й обдарованого музиканта. Коли ми говоримо про високий рівень вокально-виконавської культури, маємо на увазі і міцну технічну базу, $\mathrm{i}$ яскраву виконавську майстерність, i загальне відчуття домірності усіх музичних елементів і якісних характеристик, об'єднаних у художню цілісність.

Формування високої вокально-виконавської культури студентів $\epsilon$ головним результатом освітньої діяльності в сфері вокального мистецтва й педагогіки.. На заняттях по сольному співу розвиваються голосові дані студента, вокальний слух, уміння почувати й гнучко вести музичну фразу, виразне інтонування, а також яскрава, емоційна подача слова; закладаються такі найважливіші виконавські якості, як почуття стилю, знання жанрової специфіки, детальне прочитання авторського задуму. Важливою ланкою для розвитку індивідуальності $\epsilon$ розкриття внутрішніх особистісних якостей студента, його фантазійне, образне мислення, темперамент, характер.

Розвиток компетентності майбутніх педагогів-музикантів у цьому питанні $\epsilon$ однією 3 найважливіших завдань професійної освіти. Це зобов'язує тих, хто займається підготовкою фахівців, постійно удосконалювати навчальний процес, приводячи його у відповідність із сучасними вимогами.

Ключові слова: вокал; вокальне мистецтво; вокально-виконавська манера; мистецька школа; вокальна школа; виконавство; професіоналізація; заклади вищої освіти.

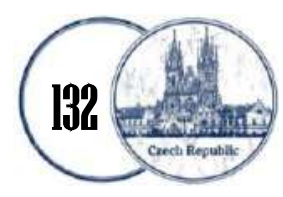




\title{
Petro Voloshyn
}

\author{
Associate Professor of Musicology and Vocal and Choral Arts, \\ Honored Worker of Culture of Ukraine. \\ Uman State Pedagogical University named after Pavel Tychyna. \\ Uman, Ukraine, \\ https://orcid.org/0000-0002-6235-8003
}

\section{VOCAL-PERFORMANCE MANNER AS A CREATIVE FACTOR OF MODERN VOCAL ART}

\begin{abstract}
The article systematizes and summarizes information about the features of the vocal and performing manner as a creative factor of modern vocal art. The very concept of "vocal and performing culture" integrates numerous components of professional singing and is a defining indicator of a good singer and gifted musician. When we talk about a high level of vocal and performing culture, we mean a strong technical base, bright performing skills, and a general sense of proportionality of all musical elements and qualitative characteristics combined into artistic integrity.

The formation of high vocal and performing culture of students is the main result of educational activities in the field of vocal art and pedagogy. In solo singing classes, the student's voice data, vocal hearing, the ability to feel and flexibly conduct a musical phrase, expressive intonation, as well as a bright, emotional presentation of the word, developed; it should be noted the most important performing qualities, such as a sense of style, knowledge of genre specifics, a detailed reading of the author's plan. An important link for the development of individuality is the disclosure of the student's internal personality qualities, his fantasy, figurative thinking, temperament, character.

The development of the competence of future teacher-musicians in this matter is one of the most important tasks of professional education. This obliges those involved in the training of specialists to constantly improve the educational process, bringing it into line with modern requirements.

Keywords: vocals, vocal art, vocal-performing manner, art school, vocal school, performing, professionalization, laying down of higher education
\end{abstract}

Постановка проблеми. Актуальність вибору теми даного дослідження обгрунтована рядом сучасних тенденцій у розвитку вокальної освіти в Україні.

Інтерес до вокального мистецтва наразі фіксується серед представників усіх поколінь. Росте кількість співочих колективів, відкриваються численні вокальні студії, організуються вокальні класи в музичних і загальноосвітніх школах, де $\epsilon$ можливості вибору для творчого розвитку будь-яких видів

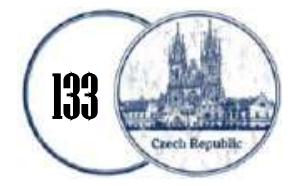


Věda a perspektivy № 2(9) 2022

ISSN 2695-1584 (Print)

ISSN 2695-1592 (Online)

вокального виконавства академічний, народний, естрадний, джазовий, хоровий спів. Щорічно в нашій країні й за кордоном проводиться велике число вокальних конкурсів за участю дітей і молоді різних вікових категорій, що говорить про надзвичайну популярність даного виду творчості.

Дослідження вказують на особливу роль співу в системі музичноестетичного виховання дітей. Вокально-виконавська творчість позитивно впливає на всебічне виховання й освіту, музичний розвиток дітей і юнацтва, впливаючи на емоційну сферу, розвиваючи художній смак, виховуючи естетичну культуру.

Взаємопов'язаність даної дослідницької проблеми із важливими питаннями інших наук. Питання, що актуалізується у даній статті, пов'язано 3 рядом наукових дисциплін, зокрема культурологією, технікою вокального виконавства, теорію мистецтва співу та ін.

Аналіз останніх досліджень i публікацій. Як показали результати проведених досліджень [3, 6, 7], сьогодні серед проблем виховання молоді однією із самих гострих можна назвати зниження рівня художньо-естетичних потреб. Основна маса школярів зорієнтована головним чином на зразки масової молодіжної музики низької якості, що не відповідає критеріям художності. Сучасні дослідження показують також недостатній серед дітей шкільного віку рівень знання народної вокальної музики [8].

Метою даної публікації є систематизація й узагальнення відомостей про особливості вокально-виконавської манери як творчого чинника сучасного вокального мистецтва.

Виклад основного матеріалу. У наші дні інтерес до вокального мистецтва надзвичайно високий. Проблема розвитку й навчання співака, удосконалення його виконавської майстерності викликає великий інтерес. Безумовно, історією вже накопичені матеріали із вивчення будови й роботи голосового апарата, описані вокально-педагогічні принципи, методи, вокальні школи минулих епох. Процес збагнення співочого мистецтва - це дуже захоплюючий, але складний, тривалий процес, який вимагає і від педагога, і від учня взаєморозуміння, чимало духовних $\mathrm{i}$ фізичних сил, терпіння, щоби добитися бажаного результату, а саме гарного тембрального звучання, професійного володіння голосом, яскравого музичного враження.

Сучасна концепція навчання сольному співу не може обмежуватися винятково практичними заняттями, а вимагає розуміння закономірностей співочого процесу й знання історії вокального мистецтва. Саме цілісний вплив $\epsilon$ найбільш ефективним педагогічною установкою й дозволяє досягнути єдності вокально-виконавської практики й завдань вокальної освіти. На сьогоднішній момент практика навчання сольному співу підкріплена введеними в навчальний 
план лекційними курсами, присвяченими основам методики постановки голосу, історії вокальної педагогіки й виконавства.

Для творчих кафедр, зокрема кафедри сольного співу, “освітні інновації” передбачають розв'язання наступних конкретних завдань:

активізація творчого, особистісного потенціалу

професорсько-викладацького складу й студентів, мобільність у роботі колективу;

створення нових умов для досягнення якісних змін у музичнопедагогічній діяльності;

відновлення поглядів і практичних дій у розв'язанні питань навчального характеру;

- $\quad$ формування сучасного науково-методичного забезпечення (у тому числі розробка нових програм) і творчого, динамічного середовища для глибокого, всебічного розвитку учнів / студентів.

Л.Г.Арчажникова писала: "Виступаючи як виконавець, педагог учить хлопців розуміти й оцінювати музику, управляти їхніми емоціями. А це дуже важливо, тому що іноді музикою можна переконати більше, ніж авторитетними вказівками" [2, с. 85]. При цьому, на ii думку, особлива увага повинна приділятися не вузько-виконавській підготовці, а вихованню виконавської культури майбутнього педагога-музиканта, яка "повинна відображати його розвинений естетичний смак, свідоме відношення до музичного мистецтва, широту кругозору, що проявляється в знайомстві із кращими творами світової музичної культури, готовність до музично-просвітницької роботи” [2, с. 70].

Процес музичного виховання, розвитку й навчання виходить із художньозмістовного, емоційно-виразного змісту самої музики. Отже, педагогічна діяльність учителя-музиканта повинна будуватися на розумінні виховної сили музики й пошуку найбільш ефективних шляхів введення учнів в іï різноманітний світ, серед яких одним 3 найдієвіших є його власне виконання, вокальне або інструментальне.

Основна відмінність професійної роботи педагога-музиканта від викладачів інших дисциплін полягає в тому, що його педагогічна діяльність сполучає функції й викладача, і музиканта-виконавця. Вокально-виконавську культуру слід характеризувати як рівень майстерності та компонент вокальнопедагогічної культури вчителя музики. Ця точка зору дозволяє виділити вокально-виконавську культуру педагога-музиканта як значиму складову його професійно-педагогічної культури, оскільки остання являє собою загальну культуру й виконує функцію специфічного проектування загальної культури в сферу педагогічної діяльності.

Аналіз теоретичної літератури $[1,3,5]$ дозволяє зробити висновок про те, що музичне виконавство (вокальне, інструментальне) займає значне місце в

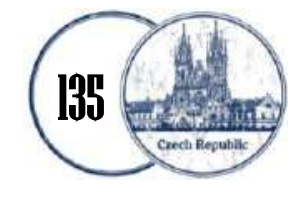


музичному вихованні дітей. 3 іншого боку, для перетворення даного виховного засобу в освітній процес необхідне формування виконавської культури в самого майбутнього педагога-музиканта.

Практика показує, що вокальна підготовка студентів, майбутніх педагогівмузикантів, традиційно спрямована на розвиток комплексу вузько-специфічних професійних умінь і навичок. Педагоги-вокалісти основну увагу приділяють розвитку вокально-технічних виконавських якостей співочого голосу, але при цьому мало використовують педагогічний потенціал навчальних дисциплін вокально-виконавського циклу у вихованні особистості майбутнього педагогамузиканта, формуванні його вокально-виконавської культури.

Не тільки той педагог-музикант зможе залучити інтерес учнів до вокального мистецтва, хто сам володіє професійними вокальними навичками, добре поставленим співочим голосом, але й той, хто має відповідні науковометодичні й історико-педагогічні знання. При цьому немаловажну роль у підготовці педагога-музиканта відіграє набуття знань про вокально-педагогічну і виконавську культуру минулого.

У будь-якому мистецтві, у тому числі й у співочому, належний розвиток практики неможливий без знання історії й належної розробки теорії. Формування високої виконавської культури майбутнього педагога-музиканта неможливе без залучення народних вокально-виконавських традицій, з яких переважно складалася музична культура минулого в процесі послідовної передачі від покоління до покоління морально-естетичного й художнього досвіду.

Для розкриття сутності поняття “вокально-виконавська культура" важливо, що власне культура це ціннісно й символічно закріплена людська діяльність та iї продукти, підтримані гуманними моральними цілями, упорядкована людська діяльність. Особливу роль він відводить мистецтву як феномену культури.

Розкриваючи поняття “вокальне виконавство”, слід виділити його у самостійний вид мистецтва. Дослідники, виробивши єдиний підхід до теорії вокальної творчості, вокальної педагогіки й виконавської практики, на основі аналізу й узагальнення закономірностей їх розвитку виявляють специфіку вокального виконавства й приходять до такого висновку [9]. Вокальне виконавство, що є одним 3 видів художньої творчості й складовою частиною мистецтва в цілому, характеризується структурно-функціональною подвійністю: підкоряючись загальним законам функціонування різних видів мистецтв, вокальна творчість має відносну суверенність (самостійністю), представляючи собою особливий специфічний різновид художньо-творчості діяльності.

Слідуючи цій логіці, вокальне виконавство, будучи одним 3 видів мистецтва, підкоряється його законам, відображаючи навколишню дійсність

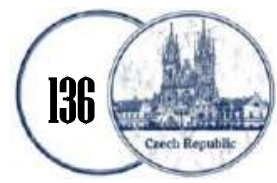


специфічними засобами співочого голосу, системою вокально-виразних засобів, тому воно має свої особливості й здатне виконувати виховну, естетичну й інші функції мистецтва як феномена культури.

Вокальне виконавство - один з найпоширеніших видів музичної творчості. Як самостійний вид художньо-творчої діяльності вокальне виконавство сформувалося у результаті поділу на композиторське й виконавське мистецтво. Такі естетичні аспекти вокального виконавства, як евристичність, варіантна множинність, процесуальність, діалектичний зв'язок традицій і новаторства, співвідношення об'єктивного й суб'єктивного, артистизм, театралізація, синестезія тощо, зближають його з іншими видами художньої творчості.

Разом із тим, вокально-виконавська творчість тісно стикається із процесом виховання й освіти. Виховну функцію вокально-виконавської творчості як одну 3 актуальних педагогічних проблем розглядають у своїх дослідженнях багато науковців. У вокальній педагогіці спів розуміють у широкому й вузькому змістах. У широкому змісті спів - це “здатність голосу виражати музичні думки" [5, с.72], у вузькому - творча діяльність людини, у процесі якої відбувається передача художнього образа музичного твору з використанням вокальної техніки.

Вокально-виконавські проблеми займали вчених ще із часів античності, що підтверджують висловлення Сократа, Платона, Аристотеля. У фундаментальних працях дослідників вокального мистецтва наводяться цінні матеріали, що стосуються історії, теорії й практики художнього співу; дається науково об'єктивна оцінка найбільш відомих вокальних шкіл, узагальнюються досягнення окремих видатних співаків і вокальних педагогів.

Сприймати спів можна, тільки почувши його. Для цього необхідна наявність виконавця. Якщо твори художників, скульпторів, архітекторів залишаються незмінними назавжди, то на музичний твір впливають i час, i епоха, а головне, виконавці. Видатні вокалісти не просто механічно повторюють текст, а $€$ інтерпретаторами музичних творів. Лише співак 3 розвиненим художнім смаком, тонким почуттям стилю, яскравим темпераментом здатний розкрити й передати слухачеві у всій повноті зміст твору, що виконується. "Поєднуючи в собі енергетику музики й слова, вокальне мистецтво стає зоною “надвисокої напруги”, концентрацією всіх життєвих сил, інтуїції тощо. I те, що породжується всім цим, є потрясінням, яке охоплює всіх учасників цього процесу" [10, с. 14].

Однак щоб бути почутим, виконавцеві необхідне вміння правильне озвучити, тобто "проінтонувати" своє виконання. Інтонація як важливий засіб художнього спілкування несе на собі велике культурно-інформативне навантаження, $є$ способом, що емоційно здійснює (сугестивного) впливу на слухача й глядача, формою передачі ціннісних орієнтацій [4, с. 168]. Інтонація в

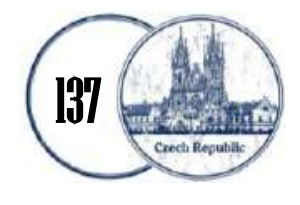


музиці як прояв людської мови, свідомості й думки розглянута в роботах видатного музикознавця академіка Б.Асафьєва. Запроваджений ним термін "зерно інтонації" дозволяє розкрити головний зміст музичного твору за допомогою закладених у даному творі музичних інтонацій.

Завдяки інтонації складаються ланки комунікативної системи: автор (виконавець), інтонаційні (виразні) засоби, сприймаючий (слухач, глядач). У педагогічному процесі ця система доповнюється ще однією ланкою вчителем [1, с. 265]. Сприйняття вокального мистецтва й сам процес вокальновиконавської художньої творчості через естетичний вплив i насолоду, одержувану людиною, здійснюють виховання, інформування, пізнання, передачу досвіду, аналіз стану світу [4, с. 106].

Теорія музичного виконавства - це відносно нова сфера вітчизняної музичнопедагогічної науки. Основні принципи історії й теорії виконавства як науки й навчальної дисципліни були розроблені в 30-і роки XX сторіччя. До цього дослідники музичного мистецтва писали головним чином методичні праці, де основна увага приділялася методиці навчання співу й грі на музичних інструментах. Основоположниками музичного виконавства як музичнопедагогічної науки є Г.Коган, Б.Струве, які прагнули розглядати виконавства в його нерозривному зв'язку з музичною культурою суспільства, його естетичними й художніми критеріями. Аналіз літератури про виконавське мистецтво, закони його історичного розвитку, естетику дозволяе говорити про найширші виховні й просвітницькі можливості як вокального, так і інших видів виконавства.

Формування вокально-виконавської культури як значимого компонента професійно-педагогічної культури педагога-музиканта зв'язане не тільки із професійними знаннями, уміннями й навичками, що здобуваються в класі сольного співу, роботі над репертуаром, але й 3 індивідуальними особливостями особистості того, якого навчають, становлять його пріоритетні професійні й загальнокультурні якості.

Вказані елементи визначили принципи, покладені в основу розвитку у студентів вокально-виконавської культури:

принцип науковості змісту й методів навчального процесу, який відбиває взаємозв'язок із сучасним науковим знанням і практикою вокального виконавства;

принцип зв'язку теорії й практики, який передбачає, щоби процес розвитку вокально-виконавської культури майбутнього педагога-музиканта передбачав використання отриманих знань, умінь і навичок у вокально-виконавській i педагогічній практиці;

принцип посилення мотивації навчання, для розвитку якої студенти повинні бачити значимість своєї майбутньої професії;

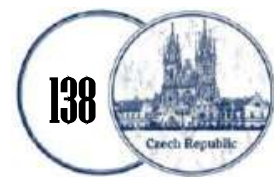


принцип співробітництва, що є актуальним для музичної педагогіки; інтелектуально-духовна співдружність викладача й студента, стаючи домінантою їх музичної життєдіяльності, створює умови для розвитку в студентів необхідних якостей;

принцип суб'єктності, орієнтований на розвиток особистості як унікальної індивідуальності;

принцип креативності, що передбачає максимальну орієнтацію на придбання досвіду творчої діяльності; принцип інтеграції, що включає використання міжпредметних зв'язків, виділення основних змістовних вузлів, угруповання знань навколо ключових тем, понять, які впливають на формування вокально-виконавської культури майбутнього педагога музиканта.

Педагог-музикант як особистість і професіонал розвивається у ході навчання, виховання, виконавської й педагогічної практики. Отже, процес формування вокально-виконавської культури майбутніх педагогів-музикантів може бути більш успішним і ефективним, якщо в ході навчально-виховного процесу будуть реалізовані такі педагогічні умови:

1. Дидактичний супровід загальнопрофесійної підготовки майбутнього педагога музиканта предметами вокально-виконавського циклу: “Клас сольного співу”, “Клас вокального ансамблю”, “Клас народного співу”, що включають комплекс практичних завдань, методичні рекомендації для самостійної роботи студентів, матеріали діагностики якості вокально-виконавської підготовки.

2. Розробка й включення в освітній процес майбутнього педагогамузиканта комплексів дисциплін: "Історія й педагогіка вокального виконавства”, “Основи традиційного вокального виконавства” на основі модульної технології навчання.

3. Оптимальна комбінація аудиторної й позааудиторної навчальної, нормативної й самостійної, концертно-практичної діяльності студентів, спрямованої на формування професійних вокально-виконавських компетенцій майбутнього педагога-музиканта.

4. Використання моніторингу як способу контролю динаміки формування вокально-виконавської культури в майбутніх педагогів-музикантів.

Кожне із цих умов має продуктивно взаємодіяти одна з одним. Однак точкою відліку для підвищення ефективності формування вокальновиконавської культури майбутніх педагогів-музикантів є розробка й включення в освітній процес навчально-методичних комплексів дисциплін “Історія й педагогіка вокального виконавства", “Основи традиційного вокального виконавства”, оскільки ці дисципліни мають досить високий педагогічний

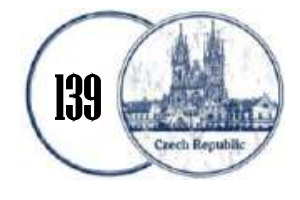


Věda a perspektivy № 2(9) 2022

ISSN 2695-1584 (Print)

ISSN 2695-1592 (Online)

потенціал для формування вокально-виконавської культури у майбутнього фахівця.

Висновки. Отже, розглянувши проблематику даної публікації, ми прийшли до наступних висновків:

Саме поняття "вокально-виконавська культура" інтегрує у собі численні складові професійного співу і $є$ визначальним показником гарного співака й обдарованого музиканта. Коли ми говоримо про високий рівень вокальновиконавської культури, маємо на увазі і міцну технічну базу, і яскраву виконавську майстерність, i загальне відчуття домірності усіх музичних елементів і якісних характеристик, об'єднаних у художню цілісність.

Формування високої вокально-виконавської культури студентів $\epsilon$ головним результатом освітньої діяльності в сфері вокального мистецтва й педагогіки.. На заняттях по сольному співу розвиваються голосові дані студента, вокальний слух, уміння почувати й гнучко вести музичну фразу, виразне інтонування, а також яскрава, емоційна подача слова; закладаються такі найважливіші виконавські якості, як почуття стилю, знання жанрової специфіки, детальне прочитання авторського задуму. Важливою ланкою для розвитку індивідуальності $\epsilon$ розкриття внутрішніх особистісних якостей студента, його фантазійне, образне мислення, темперамент, характер.

Перспективи подальших досліджень. Розвиток компетентності майбутніх педагогів-музикантів у цьому питанні є однією з найважливіших завдань професійної освіти. Це зобов'язує тих, хто займається підготовкою фахівців, постійно удосконалювати навчальний процес, приводячи його у відповідність із сучасними вимогами.

\section{Лimepamypa:}

1. Абдуллин Э. Б., Николаева Е. В. Теория музыкального образования: Москва : Издат. центр “Академия”, 2004. $336 \mathrm{c}$.

2. Арчажникова Л. Г. Профессия учитель музыки: Кн. для учителя. Москва: Просвещение, 1984. $111 \mathrm{c}$.

3. Безклубенко С. Д. Мистецтво : терміни і поняття : енциклопед. вид. : у 2 т. Київ : Ін-т культурології НАН України, 2010. Т. 2 (М-Я). 256 с.

4. Борев Ю. Б. Эстетика. Москва : Политиздат, 1988. 496 с.

5. Дмитриев Л. Б. Основы вокальной методики. Москва : Музыка, 2007. 368 с.

6. Донченко Н. П. Режисура та акторська майстерність. Київ, 2006. 260 с.

7. Зайцев В. П. Режисура естради та масових видовищ. Київ : Дакор, 2003. 304c.

8. Масол Л. М. Загальна мистецька освіта: теорія і практика. Київ, 2006. 432c.

9. Плахотнюк В. Г. Естрадний синтез мистецтв. Культура і мистеитво у сучасному світі. 2010. Вип. 11. С. 259-266.

10. Сетдикова Ю. Б. Эстетические аспекты вокально-исполнительского творчества: генезис и современные тенденции: Автореф. дис... канд. философ. наук: 09.00.04. Москва, 2006. 25 с.

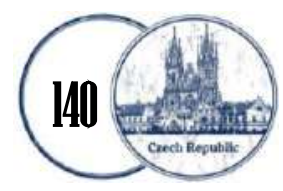




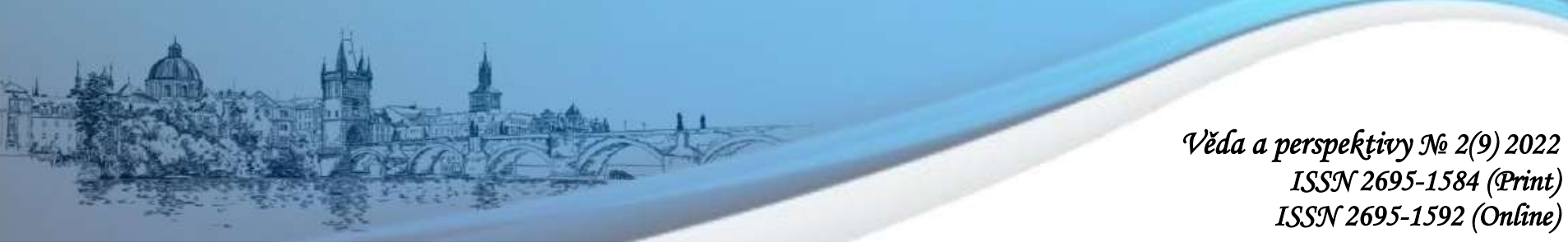

\section{References:}

1. Abdullyn, E. B., Nykolaeva E. V. (2004). Teoryia muzykalnoho obrazovanyia [Theory of music education]: Moskva : Izdat. tsentr "Akademyia" [in Russian].

2. Archazhnykova, L. H. (1984). Professyia uchytel muzyky: Kn. dlia uchytelia [Profession music teacher: Book for teacher]. Moskva : Prosveshchenye [in Russian].

3. Bezklubenko, S. D. (2010). Mystetstvo : terminy i poniattia : entsykloped. vyd.: u 2 t. [Art: terms and concepts: encyclopedic edition: in 2 volumes] Kyiv : In-t kulturolohii NAN Ukrainy. (Vol. 2) (M-Ya) [in Ukrainian].

4. Borev, Yu. B. (1988). Estetyka [Esthetics]. Moskva : Polytyzdat [in Russian].

5. Dmytryev, L. B. (2007). Osnovy vokalnoi metodyky [Basics of vocal methodology]. Moskva : Muzyka [in Russian].

6. Donchenko, N. P. (2006). Rezhysura ta aktorska maisternist [Directing and Acting]. Kyiv [in Ukrinian].

7. Zaitsev, V. P. (2003). Rezhysura estrady ta masovykh vydovyshch [Directing pop and mass spectacles]. Kyiv : Dakor [in Ukrinian].

8. Masol, L. M. (2006). Zahalna mystetska osvita: teoriia i praktyka [General art education: theory and practice]. Kyiv [in Ukrinian].

9. Plakhotniuk, V. H. (2010). Estradnyi syntez mystetstv [Pop synthesis of the arts]. Kultura $i$ mystetstvo u suchasnomu sviti - Culture and art in the modern world, (Vol 11), (pp. 259-266) [in Ukrinian].

10. Setdykova, Yu. B. (2006). Estetycheskye aspekty vokalno-ispolnytelskoho tvorchestva: henezys y sovremennye tendentsii [Aesthetic aspects of vocal and performing creativity: genesis and modern trends]. Moskva [in Russian]. 